Original article

\title{
Significance of the Lower Lip Central Groove for Determination of the Contact Between the Upper Central Incisors
}

\author{
Marko Igić1, Milena Kostić ${ }^{1}$,Nebojša Krunić ${ }^{1}$, Ana Pejčić2, Stefan Dačić ${ }^{3}$, Nenad Stošić ${ }^{3}$ \\ ${ }^{1}$ University of Niš, Faculty of Medicine, Department of Prosthodontics, Niš, Serbia \\ ${ }^{2}$ University of Niš, Faculty of Medicine, Department of Periodontology and Oral Medicine, Niš, Serbia \\ ${ }^{3}$ University of Niš, Faculty of Medicine, Department of Operative Dentistry and Endodontics, Niš, Serbia
}

\begin{abstract}
SUMMARY
Among many factors influencing human beauty, the correct position of the upper front teeth, including central incisors, is undoubtedly of particular importance. When determining the intermaxillary relationship, an important phase is determination of the medial line of a person's face or places of contact of the upper central incisors. The aim of this study was to test the hypothesis that the place of mutual contact of the upper central incisors in most cases coincided with the central groove of the lower lip.

Examination included two groups of respondents. The first group consisted of $\mathbf{1 0 0}$ female and the second of 100 male respondents, with age range from 18 to 30 years. A starting point in measuring was the central groove of the lower lip. Measuring the horizontal distance of the central groove of the lower lip and the mutual contact of the upper central incisors was performed with a slight touch of the upper teeth with the lower lip. The measurement was performed using a digital vernier $\mathrm{SH}$, with the resolution of $0.01 \mathrm{~mm}$.

After performing statistical analysis, the results showed that in a large percentage of cases, the central groove of the lower lip coincided with the point of mutual contact of the upper central incisors.

The point of contact of the upper incisors can be determined simply by transferring the position of the groove to the upper interocclusal rim, with a slight contact between the lips and interocclusal rim.
\end{abstract}

Key words: lip, incisors, groove, denture, face

Corresponding author:

Marko Igić

Email: saigic@yahoo.com 


\section{INTRODUCTION}

There are many important factors of human beauty and the dental prosthetic replacements of lost teeth and supporting structures can certainly affect them. To make this replacements aesthetically good, it is necessary to know the number of elements related to beauty and its reconstruction. In case of a lack of the upper front teeth, it is necessary to com-pensate them with either mobile or fixed prosthesis, ensuring that they are placed exactly at the right position. According to Lejoyeux, the upper front teeth are the foundation stone for setting the teeth (1). This primarily concerns their position vertically and horizontally, which is determined by the creation of the occlusion rims, with partly determined slope of the tooth by proper formation and alignment of the upper and lower occlusion rims. The definite slope is determined in a dental laboratory, which is then checked and corrected during the trial of a set of teeth in a dental office.

One of the problems to be solved, when determining the intermaxillary relationship, is anaccurate determination of the middle of the face, more precisely the contact of the upper central incisors. This place is one of the most striking spots of the human face (Figure 1) and is especially evident during smiling as an essential element of human beauty.

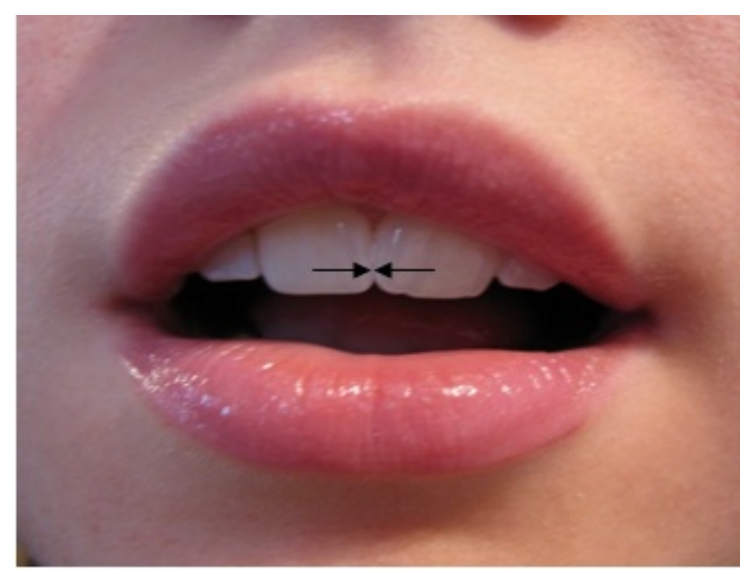

Figure 1. The contact between the upper central incisors

The contact of the lower teeth does not even need to coincide with the mid-face and is much less likely that someone will notice this anomaly. A reason for this is that the lower teeth are less visible during laughter, and even less during speaking. In addition, during speech, the attention of people is more focused on what it is being talked about than on the appearance of the speaker.

Determination of the contact point of the upper central incisors during determining the intermaxillary relationship is a very important element for the future aesthetics of dentures. Literature data show that it is necessary to mark the "centre line", "median line", "centreline persons" etc. (2-4) on the occlusion rims during the determination of the intermaxillary relations. It is usually done by observing the patient's face and its distinctive elements (nose, chin), assuming that the human face is symmetric. Then, the middle of these elements is determined and the assumed middle point is transferred to the occlusion rims. When doing so, a doctor is trying to stay right in front of the patient in order to avoid wrong estimation of a person's middle of the face that, due to inadequate position from which the face is being observed, may lead to the wrong determination of the person's middle of the face.Any error in this estimation would lead to incorrect determination of the contact point between the central incisors in dentures. Of course, it is difficult to determine the right place from which the observation should be made, and the position of the patient in the chair prevents the doctor to stand right in front of him. Thus, it is perhaps better to determine the face centre line while the patient is standing. In addition, the patient rarely holds the head fully straight. Besides, the fact is that the human face is rarely symmetrical $(1,5-11)$, with one half slightly larger than the other (the asymmetry is equally shifted to the left or right). That means that the middle of the face is moved to the side, towards the smaller half of the face. In such cases, the problem is where to set the middle line. If the teeth are set so that the contact point of the central incisors is exactly in the middle of persons face, it will not coincide with the middle of the nose and chin and aesthetic requirements will not be met. That is why some doctors recommend that teeth should be set so that the contact point is slightly shifted towards less developed half of the face and thus the elements of the face are brought into line (10). Therefore, it is not enough to use a precision instrument to determine the middle of the face, but more importantly to find a "harmonious middle of the face".

There have been attempts to determine such middle areas by determining the middle of the elements (the nose, chin and forehead), so that a thin thread or wire can connect these points.The obtained line at the point where it crosses the upper occlusion 
rim will be then transferred to the rim. However, this method has its drawbacks. It matters from which side the thread or wire is being observed, especially if a thread is thicker. When a person's face is not symmetrical, it is usually curved in an arc, and the obtained line would actually be a tangent to the arc. The further the measurement points are, the longer the tangent and more distant from the desired point would be. This means that the set teeth, according to this landmark, would be far from the desired place, and as a result of this aesthetics a disturbance will occur.

In particular, the presence of aggravating circumstances, as untidy beard and moustache, prevents the assessment of facial symmetry and precise determination of the contact of the upper central incisors. Fortunately for the dentist, those persons do not pay much attention to body image and the symmetric set of teeth, while beard and moustache conceal their teeth, making the errors less obvious.

Literature data about matching a middle line of the face with the contact point of the upper central incisors are varied and range from $20 \%$ in the Horn works, and even up to $76 \%$ in the studies of Faes $(4,12$ - 14). In the available literature, there were no data on the relationship between the central groove of the lower lip and the joint of upper central incisors.

The aim of this study was to test the hypothesis that the place of mutual contact of the upper central incisors in most cases coincides with the central groove of the lower lip.

\section{MATERIALS AND METHODS}

The respondents comprised subjects aged from 18 to 30 years, divided into two groups, with 100 male and 100 female subjects. The central groove of the lower lip served as a starting point in measuring, which is in the anatomical literature also known as the groove of the lower lip (Figure 2).

This slot is usually the deepest groove of the lower lip, but there have been some cases with deeper grooves symmetrically left and right of it (Figure 3).

In some people, the appearance of two parallel grooves is noticed instead of the central one. In such cases, the mean distance between the grooves was used for measurement.
Measuring the horizontal distance of the central groove of the lower lip and the mutual contact of the upper central incisors is by making a slight con-

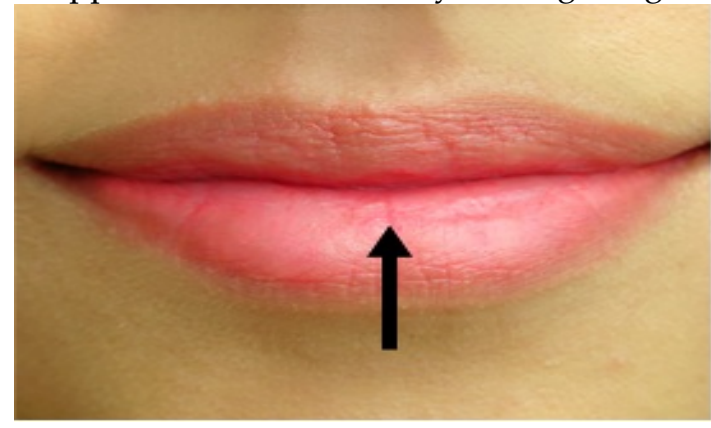

Figure 2. The lower lip central groove

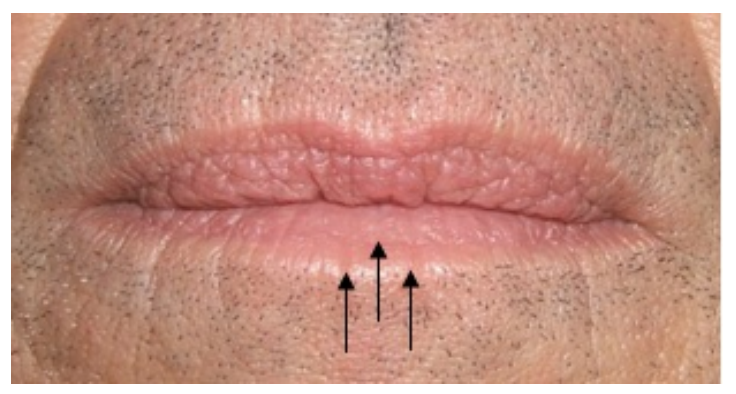

Figure 3. Lateral grooves may be deeper than the central sulcus

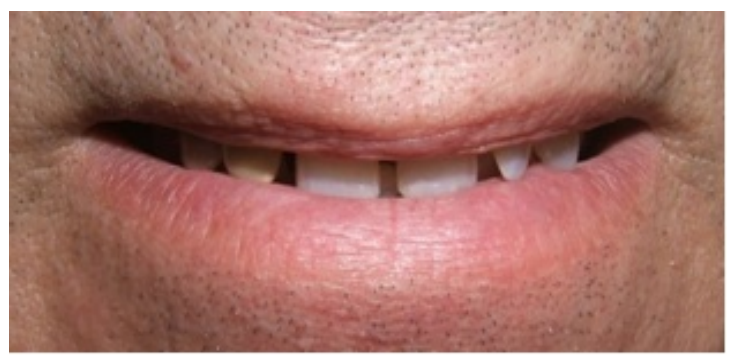

Figure 4. Slight contact between the upper teeth and the lower lip

tact between the upper teeth and the lower lip (Figure 4). In order to obtain the correct position of the teeth relative to lip, as this position is similar to the contact between the teeth and lip during pronunciation of labiodentals, a respondent is instructed first to pronounce the voice " $F$ ", and then to smile gently. In this way, the desired mild contact between the lips and teeth is achieved, but with the teeth and the groove remaining clearly visible.

In the case that there is a space between incisors, the so-called median diastema, the middle of the diastema was used for measurement. In order to accurately measure the space in such cases, the 
measurement is carried out from the medial edge of the nearest central incisor. Then, the distance of teeth (diastema width) is measured and the obtained value is divided by two to obtain the half-width of the diastema. The obtained value, depending on whether the central groove lip is inside or outside the diastema, was subtracted or added and the value for a horizontal distance of the central groove of the lower lip and of the mutual contact of the upper central incisors was obtained.

The measurement is performed using a digital vernier SH (Figure 5), with a resolution of $0.01 \mathrm{~mm}$. To get more accurate results, each measurement is repeated three times and the average value is taken.

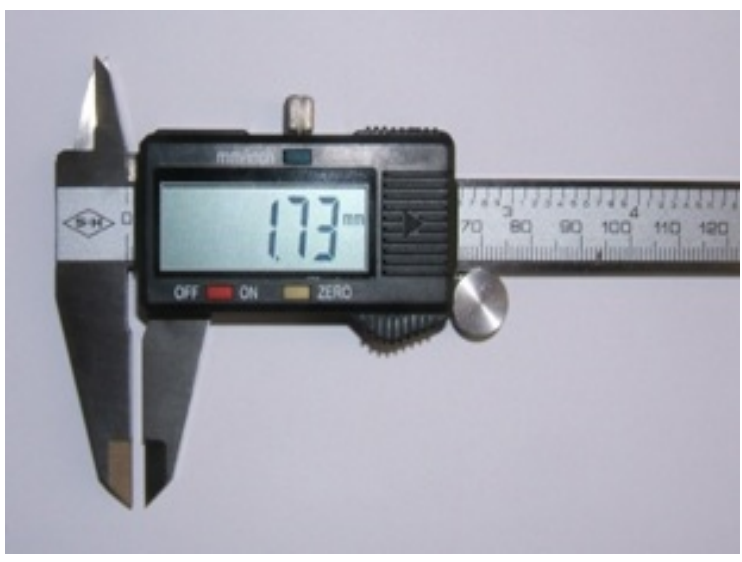

Figure 5. Digital vernier

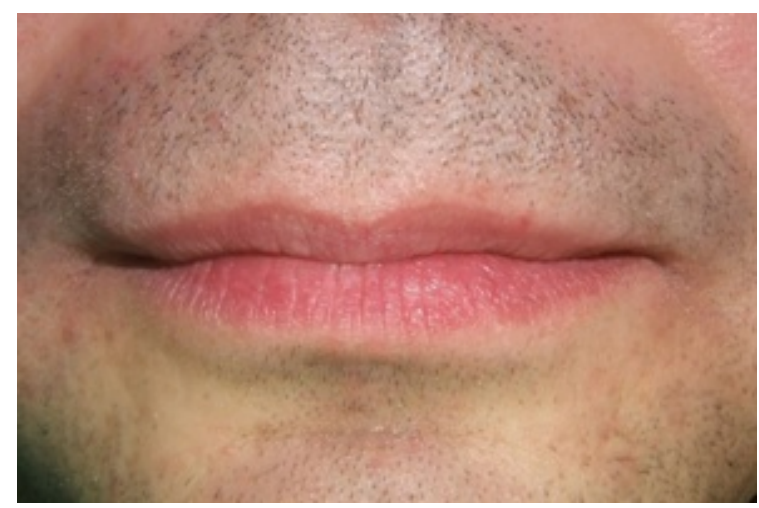

Figure 6 A large number of equally deep grooves on the lower lip

\section{RESULTS}

Of 100 males, the measurements could not be performed in 12 cases, because of unclear groove in the lips (9 subjects), or a skewed groove, which could not be used as a measuring point (three subjects).
Besides single grooves, four double and one triple groove were found. Of 88 measurable patients (Graph 1), 53 had no deviation of the contact point of central incisors in relation to the position of the central groove of the lower lip, which is $60.23 \%$. In 18 cases $(20.45 \%)$, the middle was shifted to the left and in 17 $(19.32 \%)$ to the right. Deviation of more than one millimetre was found in $11.37 \%$ of respondents, of which $4.55 \%$ to the left and $6.82 \%$ to the right. Within the tolerance of one millimetre, there were $88.63 \%$ of respondents.

Of 100 female respondents, the measurements could not be performed in 5 of them, because the lip groove was unclear. Beside a single one, three double grooves were found. Of 95 measurable patients (Graph 2), 66 (69.47\%) of them had no deviation of the contact point of the central incisors in relation to the position of the central groove of the lower lip.In 15 patients $(15.79 \%)$, the middle has been moved to the left and in $14(14.74 \%)$ shifted to the right. Deviation of more than one millimetre was found in $7.37 \%$ of patients, of which in $3.16 \%$ to the left and in $4.21 \%$ to the right. Within the tolerance of one millimetre, there were $92.63 \%$ of the patients.

The results showed that in a large percentage of cases $(69.47 \%$ were females and $60.23 \%$ were males) with mild contact between the upper teeth and the lower lip, the central groove of the lower lip coincided with the point of mutual contact of the upper central incisors.

\section{DISCUSSION}

In the female respondents, a lower percentage of vague grooves and a higher percentage of overlap of the central groove of the lower lip with the point of mutual contact of the upper central incisors was observed. This is consistent with the Takahaski's (15) findings that the asymmetry of the face in men is greater than in women. It must be noted that the method is not applicable to:

- individuals with no obvious groove;

- when there are more grooves of equal depth (Figure 6) and it is difficult to determine which of them is the central one;

-when the groove is slant,and although there is only one groove, it is not useful for determining the mid-face.

In such cases we must choose another way of determining the middle of the face. 
The accuracy affects a proper formatting of the upper occlusion rim. In order to make a proper con-

tact and good visibility of the groove when determining the intermaxillary relationship, the occlusion rim must be designed to provide pronunciation of the sound "F" withuot any problem $(16,17)$, while the top of the wall just slightly touches the lower lip in place of the juncture of the dry and wet part, or just inside that juncture, as recommended by End (18).

\section{CONCLUSION}

It can be concluded that the described method, by simple transposition of the lower lip groove localization to the occlusion rim, with a slight contact between the lips and rims, can be used in a large percentage of patients, for the determination of the contact point of the upper incisors.

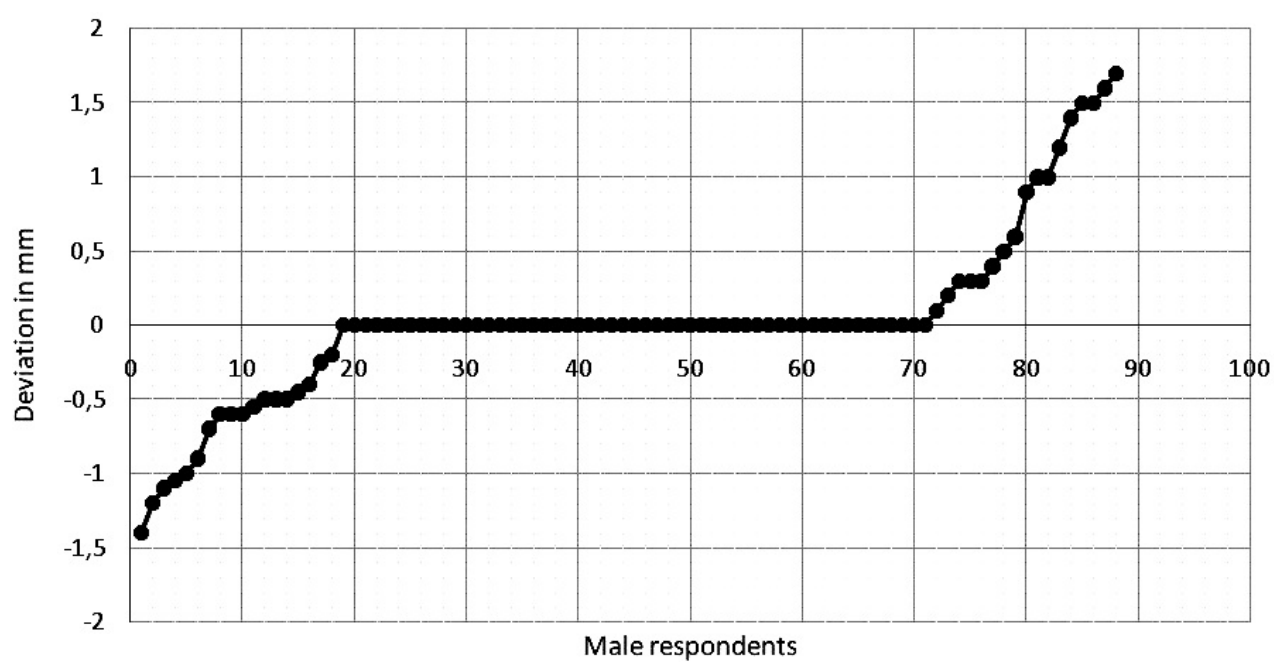

Graph 1. Deviation of the contact point of central incisors in male patients

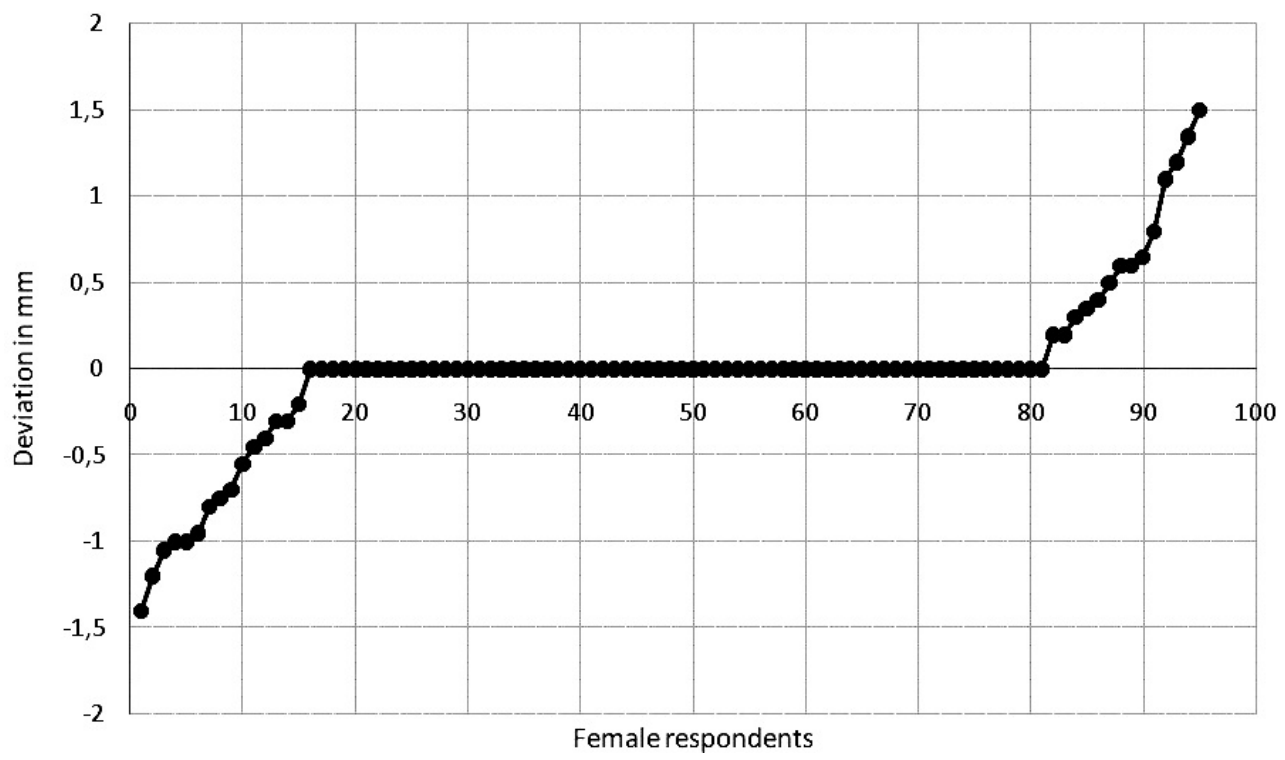

Graph 2. Deviation of the contact point of central incisors in female patients 


\section{References}

1. Lejoyeux J. Prothese complete, Tome II. Paris, Librarie Maloine, 1976.

2. Ralev R. Denture esthetics. Face. Sofia, Quintessence BG, 1993.

3. Schlosser R, Gehl D. Complete denture prosthesis. Philadelphia\&London, W. B. Saunders Company, 1953.

4. Schwindling $\mathrm{R}$, Bahr U. Lichtschnittmessungen am menschlichen Gesichtsschadel zur Uberprufung der prosthetiscen Orientirungslinien und Bezugspunkte. ZWR 1974; 83: 771-7.

5. Caltabiano M, Versi P. Valutazione delle asimmetrie facciali con una nuova metodica mediante tracciato su fotografia frontale. Min Stom 1985; 34: 853-7.

6. Cretot M. L architecture dento-faciale humaine. Paris, Julien Prelat, 1975.

7. Geering A, Kundert M, Kelsey C. Complete Denture and Overdenture. New York, Thieme Medical Publishers, Inc. 1993.

8. Kurlyandski V. Ortopedic stomatology. Moscow, Mir publishers, 1977.

9. Schlunke E. Die Asthetik der Prothetik (I). Die Quintessenz 1981; 4: 689-700.
10. Sears V.H. New teeth for old. St Louis: The C. V. Mosby Company, 1952.

11. Uhlig H. Zahnersatz fur Zahnlose. Buch und Zeitschriften - Verlag. Berlin: „Die Quintessenz", 1970.

12. Faes R. Naturliche und Künstliche obere fronzahnreihe. Schweiz Monats-schr. Zahnheilkd. 51; 1941: 785-90.

13. Horn R. Zur individuellen Gestaltung der Front in der Totalprotetik. Dtsch. Zahnarztl. Z. 37, 1982; No 3, 208-216.

14. Ralev R, Todorova V, Kalčev A. Sotnošenijana linijata meždu centralnite rezci sas srednata linija na liceto. Stom. (S) 1988; 70: 28-33.

15. Takahaski K. A study on the Symmetry of Human Faces With Reference to their Surface Areas and Volumes. J Nihon Univ Sch. Dent 1985; 27: 87-104.

16. Sokolović B.Totalna zubna proteza i estetika. Niš: Prosveta, 1998.

17. Sokolović B. Fonetski aspekti totalne zubne proteze. Dostignuća u stomatološkoj protetici. Zagreb: Sveučilišna naklada Liber, 1977.

18. End E. Physiological Occlusion of Human Dentition. Diagnosis \& Treatment. Munchen: Verlag Neuer Merkur Gmbh, 2006. 


\title{
Značaj centralnog žleba donje usne za određivanje kontakta između gornjih centralnih sekutića
}

\author{
Marko Igić ${ }^{1}$, Milena Kostić1, Nebojša Krunić ${ }^{1}$, Ana Pejčić ${ }^{2}$, Stefan Dačić ${ }^{3}$, Nenad Stošić3 \\ ${ }^{1}$ Univerzitet u Nišu, Medicinski fakultet, Katedra za stomatološku protetiku, Niš, Srbija \\ ${ }^{2}$ Univerzitet u Nišu, Medicinski fakultet, Katedra za oralnu medicinu i parodontologiju, Niš, Srbija \\ ${ }^{3}$ Univerzitet $u$ Nišu, Medicinski fakultet, Katedra za bolesti zuba i endodonciju, Niš, Srbija
}

\section{SAŽETAK}

Među brojnim činiocima ljudske lepote, pravilan položaj gornjih prednjih zuba, uključujući centralne sekutiće, nesumnjivo je od posebnog značaja. Prilikom određivanja međuviličnih odnosa, značajna faza je pronalaženje sredine lica ili mesta kontakta gornjih centralnih sekutića. Cilj ovog istraživanja bilo je testiranje hipoteze o tome da se mesto kontakta gornjih centralnih sekutića, u većini slučajeva, poklapa sa central-nim žlebom donje usne.

Ispitivanje je uključilo dve grupe ispitanika. Jedna grupa sastojala se od 100 ženskih, a druga od 100 muških ispitanika, starosti od 18 do 30 godina. Početna tačka u merenju bio je centralni žleb donje usne. Merenje horizontalnog razmaka između centralnog žleba donje usne i mesta kontakta gornjih centralnih sekutića rađeno je pri blagom kontaktu gornjih zuba i donje usne. Merenje je vršeno korišćenjem digitalnog šublera $\mathrm{SH}$, rezolucije $0,01 \mathrm{~mm}$.

Nakon statističke analize, rezultati su pokazali da se, u većini slučajeva, centralni žleb donje usne poklapa sa mestom kontakta gornjih centralnih sekutića.

Mesto kontakta gornjih centralnih sekutića može biti određeno jednostavnim prenošenjem položaja centralnog žleba donje usne na gornji zagrižajni bedem, pri blagom kontaktu usana i zagrižajnog bedema.

Ključne reči: usna, sekutići, žleb, proteza, lice 